\title{
KSIECGA PROROKA ZACHARIASZA W EGZEGEZIE DYDYMA ALEKSANDRYJSKIEGO I ŚW. HIERONIMA
}

Starożytność chrześcijańska pozostawiła wiele dzieł poświęconych Pismu Świętemu. Pośród nich na uwagę zasługują komentarze biblijne do poszczególnych ksiąg Starego i Nowego Testamentu. Z całą pewnością powstawanie tych komentarzy wiązało się z potrzebą czasu, ponieważ rosnąca w siłę i ciągle rozwijająca się religia chrześcijańska potrzebowała wyjaśnienia wielu kwestii zawartych w Bożym Objawieniu. Dlatego autorzy wspomnianych komentarzy przywiązywali ogromną wagę do swojego biblijnego wykształcenia. Podejmowali często studia teologiczne, filozoficzne, topograficzne i geograficzne, zwłaszcza w odniesieniu do Palestyny, a także językowe, które miały im pomóc wykładać w sposób kompetentny treści biblijne ${ }^{1}$. Służyły temu również szkoły egzegetyczne założone w wielkich ośrodkach życia religijnego, politycznego i gospodarczego, jak chociażby w Aleksandrii czy w Antiochii.

Ważnym przedstawicielem a jednocześnie też kierownikiem szkoły aleksandryjskiej był niewidomy egzegeta Dydym zwany Ślepym lub też po prostu Dydymem Aleksandryjskim. Tragiczne jego losy po śmierci (potępiony na Soborze Konstantynopolitańskim II w 553 r. za orygenizm, rehabilitowany przez Sobór Florencki w 1439 r.), sprawiły, że wiele jego dzieł zaginęło lub zostało bezpowrotnie zniszczonych. Dopiero rok 1941 stał się dla Dydyma jakby powtórnym narodzeniem². Odkryto wówczas część jego komentarzy

* Ks. prof. dr hab. Bogdan Czyżewski - profesor nadzwyczajny w Zakładzie Teologii Patrystycznej i Historii Kościoła na Wydziale Teologicznym Uniwersytetu im. Adama Mickiewicza w Poznaniu; e-mail: czybo@amu.edu.pl.

${ }^{1}$ Por. S. Wielgus, Badania nad Bibliq w starożytności i w średniowieczu, Lublin 1990, 22-23.

${ }^{2} \mathrm{~W}$ Polsce ukazało się w ostatnim czasie kilka publikacji na temat Dydyma. Do najważniejszych należą m.in. następujące prace: B. Czyżewski, Chrystologia w Komentarzu do Zachariasza Dydyma Aleksandryjskiego, Gniezno 1996; tenże, Dydym Aleksandryjski-Ojciec zapomniany, SG 11 (1997) 305-312; tenże, Obraz Kościoła w Komentarzu do Zachariasza Dydyma Aleksandryjskiego, VoxP 28 (2008) t. 52/1, 109-122; K. Kaoka, Aretologia Dydyma Aleksandryjskiego, Lublin 2014 (mps AKUL); R. Nakonieczny, Terminologia antropologiczna w Komentarzu do Ksiegi Rodzaju Dydyma Aleksandryjskiego, Katowice 2004 (mps AUŚ); tenże, O antropologii Dydyma Aleksandryjskiego (In Genesim), Katowice 2005; tenże, Teologia kreacji - między obrazem a podobieństwem (na podstawie In Genesim Dydyma Aleksandryjskiego), VoxP 25 (2005) t. 48, 105-123; tenże, Nauka o duszy $w$ antropologii Dydyma Aleksandryjskiego, „Symbolae Philologorum Posnaniensium Graecae et 
biblijnych w małej miejscowości Tura pod Kairem, pośród nich zaś Komentarz do Zachariasza, którego tekst w większości się zachował³.

Nie tylko Dydym Aleksandryjski napisał komentarz do wspomnianej księgi Starego Testamentu. Uczynił to także św. Hieronim, który znał niewidomego egzegetę, co więcej, był w pewnym stopniu inspiratorem dla niego, ponieważ poprosił go o napisanie takiego właśnie komentarza. W niniejszym artykule spróbujemy ocenić egzegezę jednego i drugiego komentatora w odniesieniu do Ksiegi proroka Zachariasza, a przede wszystkim zobaczyć, czy istnieje pomiędzy przekazanymi przez nich interpretacjami jakaś zależność.

1. Co lączyło Dydyma z Hieronimem? Powyższe pytanie jest w pełni uzasadnione, a udzielona na nie odpowiedź pomoże z pewnością lepiej zrozumieć, dlaczego zestawiamy te dwie osoby, mianowicie Dydyma Ślepca i św. Hieronima. Na początku należy wyjaśnić, że niewątpliwie łączy ich komentarz do Księgi proroka Zachariasza. Jeden i drugi zinterpretował bowiem ten starotestamentowy tekst $\mathrm{w}$ bardzo podobny sposób. Zanim jednak przyjrzymy się dokładnie ich egzegezie, warto poszukać jeszcze innych związków, jakie wiążą Dydyma i Hieronima.

Otóż św. Hieronim dosyć często wspomina o niewidomym egzegecie z Aleksandrii ${ }^{4}$. W De viris illustribus datowanym na 392 r. pisze, że Dydym „,̇yje dotąd i osiemdziesiąty trzeci rok przekroczył" . Hieronim przekazuje też informację na temat ślepoty Dydyma. Stwierdza on, że ,jeszcze jako dziecko utracił wzrok, zanim się nauczył czytać i pisać" ${ }^{6}$. Ten sam Hieronim w Liście 68. skierowanym do Kastrucjusza ${ }^{7}$ opisuje wizytę, jaką Dydym złożył św. Antoniemu. Eremita miał go wtedy zapytać:

Latinae" 21 (2011) fasc. 2, 157-180; R.M. Pancerz, Hermeneutyka antropomorfizmów biblijnych u Dydyma Ślepego, VoxP 30 (2010) t. 55, 521-534; M. Szram, Elementy pitagorejskiej symboliki liczb w dziełach Dydyma Ślepego, „Studia Graeco-Latina” 4 (2002) 165-179. Całość bibliografii na temat Dydyma (zarówno publikacje polskie jak i obcojęzyczne) por. D. Szymańska-Kuta, Dydym Ślepy. Materiały bibliograficzne, VoxP 35 (2015) t. 63, 567-581.

${ }^{3}$ Por. Czyżewski, Chrystologia w Komentarzu do Zachariasza, s. 13.

${ }^{4}$ Dydym urodził się prawdopodobnie ok. 313 r. umarł zaś w roku 398. Więcej na temat chronologii życia Dydyma i związanych z tym hipotez zob. G. Bardy, Didyme l'Aveugle. Essai de théologie historique, Paris 1910, 3. Z kolei L. Doutreleau (Vie et survie de Didyme l'Aveugle du $I V^{e}$ siècle à nos jours, „Les Mardis de Dar El-Salam” (1956-57), Paris - Le Caire 1959, 33-92) podaje obszerną biografię egzegety z Aleksandrii

${ }^{5}$ Hieronymus, De viris illustribus 109, PL 23, 705, thum. W. Szołdrski: Św. Hieronim, O znakomitych mężach, PSP 6, Warszawa 1970, 122. Trudno jest przyjąć bezkrytycznie wymienioną liczbę lat, ponieważ inne manuskrypty zawierające dzieło św. Hieronima podają jeszcze inne lata: 80, 84, nawet 87 (por. Czyżewski, Dydym Aleksandryjski-Ojciec zapomniany, s. 306-307).

${ }^{6}$ Hieronymus, De viris illustribus, 109, PL 23, 705, PSP 6, 122.

${ }^{7}$ Kastrucjusz pochodził z Panonii, był ślepy, udał się jednak na pielgrzymkę do Ziemi Świętej, by tam spotkać się ze św. Hieronimem. Kiedy dotarł do wybrzeża dalmatyńskiego, zatroskani o niego przyjaciele poprosili go, by zawrócił z drogi. 
„«Czy nie jesteś smutny, że nie masz wzroku zmysłowego?» Gdy tamten milczał ze wstydu, zapytał go po raz drugi i trzeci, i wydobył z niego wreszcie szczere wyznanie, że się w duszy smuci z tego. Na to mówi mu Antoni: «Dziwię się, że mąż roztropny ubolewa nad utratą tego, co mają mrówki, muchy i komary, a nie cieszy się z posiadania tego, na co zasłużyli jedynie święci i apostołowie»" ".

Dydym stał się też nauczycielem dla Hieronima, o czym sam wspomina w Liście 84. skierowanym do Pammachiusza i Oceana:

„Już głowa okryła się siwizną i przystało mi raczej być nauczycielem niż uczniem, udałem się jednak do Aleksandrii, gdzie słuchałem Didyma. Za wiele rzeczy składam mu dzięki. Czego nie umiałem, tego nauczyłem się; tego zaś, co umiałem, nie straciłem wskutek jego wykładów"9.

Okazuje się, że Hieronim był tam tylko 30 dni, w odróżnieniu od Rufina z Akwilei, który uczył się u Dydyma 8 lat ${ }^{10}$. Rufin w Apologii przeciw Hieronimowi przytoczył fragment wstępu do dzieła Dydyma O Duchu Świętym, w którym Książę Egzegetów napisał o Aleksandryjczyku, że chociaż

„nie ma biegłości w wysłowieniu się, ale posiada wiedzę, dając się poznać jako mąż apostolski po samym sposobie pisania zarówno dzięki ważności myśli, jak i prostocie stylu"11.

Kiedy rozpoczęły się spory o Orygenesa, Hieronim wycofywał się oczywiście z tego i tłumaczył, że były to tylko wyrazy czci i pozdrowienia (honorem et salutationem) wymagane w liście, posądzanie go natomiast o kontakty z byłym nauczycielem jest niedorzeczne i bezpodstawne (inepta sunt haec et frivola) ${ }^{12}$.

Dydyma i Hieronima, o czym już wcześniej była mowa, łączy przede wszystkim komentarz do księgi proroka Zachariasza. Nie chodzi jednak tylko o samo dzieło, ale także o historię jego powstania. Hieronim poprosił bowiem Dydyma o napisanie tego komentarza i stał się w pewnym sensie jego inspiratorem. W Hieronimowym wstępie do Komentarza do proroka Ozeasza czytamy:

„Kiedy byłem w Aleksandrii, widziałem Dydyma [...] i poprosiłem go, aby, co Orygenes nie uczynił, on sam uzupełnił i napisał do Ozeasza komentarzy ksiąg trzy, które mi podarował, także pięć innych ksiąg do Zachariasza"13.

${ }^{8}$ Tenże, Epistula 68, 2, ŹMT 55 [wyd. łacińsko-polskie, tekst łac. i oprac. H. Pietras, thum. J. Czuj, oprac. M. Ożóg, t. 2: Listy 51-79], Kraków 2010, 150-150*.

${ }^{9}$ Tenże, Epistula 84, 3, ŹMT 61 [wyd. łacińsko-polskie, tekst łac. i oprac. H. Pietras, thum. J. Czuj, oprac. M. Ożóg, t. 3: Listy 80-115], Kraków 2011, 25-25*.

${ }^{10}$ Por. J. Żelazny, Wstęp, w: Św. Rufin z Akwilei, Obrona przed zarzutami Hieronima, ŹMT 29, Kraków 2003, 7.

${ }^{11}$ Rufinus, Apologia contra Hieronymum II 27, ed. M. Simonetti, CCL 20, Turnholti 1961, 103, thum. A. Smaroń: Św. Rufin z Akwilei, Apologia przeciw Hieronimowi, w: Św. Rufin z Akwilei, Obrona przed zarzutami Hieronima, ŹMT 29, Kraków 2003, 126.

${ }_{12}$ Por. Hieronymus, Epistula 84, 3, ŹMT 61, 26-26*.

${ }^{13}$ Tenże, Prologus in Osee prophetam, PL 25, 820A: „Cum essem Alexandriae, vidi Didymum 
Informację tę potwierdził Hieronim w De viris illustribus, gdzie chwali Dydyma iż

„napisał wiele znakomitych dzieł (plura opera conscripsit): [...] do Ozeasza komentarzy ksiąg trzy, które mnie dedykował (in Osee, ad me scribens, commentariorum libro tres), i na moją prośbę do Zachariasza ksiąg pięć (et in Zachariam, meo rogatu, libros quinque)"14.

Także w swoim Komentarzu do proroka Zachariasza, raz jeszcze św. Hieronim powtórzył, że

„Didymus quinque explanationum libros, me rogante, dictavit, quos cum aliis tribus in Osee et mihi $\pi \rho 0 \sigma \varepsilon \varphi \omega ́ v \eta \sigma \varepsilon v " 15$.

Geneza zatem powstania interpretacji biblijnej Księgi proroka Zachariasza jest stosunkowo jasna. Dydym sporządził swój komentarz na prośbę Hieronima. Powstaje jednak pytanie, dlaczego Hieronimowi tak bardzo zależało na tym komentarzu? Czyżby chciał poznać wyjaśnienie wielu kwestii egzegetycznych zaproponowanych przez Dydyma, który niewątpliwie był dla niego autorytetem? A może pojawił się inny powód prośby Hieronima?

2. Dwa czy jeden komentarz do proroka Zachariasza? Powyższe pytanie jest dosyć prowokacyjne, ale też całkowicie świadome. Spróbuję wyjaśnić, dlaczego się ono w ogóle pojawiło. Otóż najpierw należy powiedzieć kilka słów na temat historii powstania Komentarza do proroka Zachariasza autorstwa Hieronima. Przypomnijmy, że komentarz Dydyma Aleksandryjskiego odkryto przypadkowo w ubiegłym stuleciu, dokładnie zaś w roku 1941 w małej miejscowości Tura, $12 \mathrm{~km}$ na południe od Kairu, podczas czyszczenia groty. Pośród odnalezionych tam pism znajdował się Komentarz do Zachariasza Dydyma Aleksandryjskiego, jedyny komentarz biblijny tego autora zachowany w większej części ${ }^{16}$.

Okazuje się, że autentyczność komentarza Dydyma Aleksandryjskiego odnalezionego w Tura można udowodnić nie tylko na podstawie wcześniej cytowanych wypowiedzi św. Hieronima, ale także w oparciu o komentarz do tego samego proroka autorstwa Księcia Egzegetów. Wcześniej stwierdziliśmy, że Hieronim poprosił Dydyma, by ten napisał komentarz do proroka Zachariasza. Na tym jednak nie zakończyła się historia tej prośby i tekstu, w wyniku której

[...] rogavique eum ut quod Origenes non fecerat, ipse compleret, et scriberet in Osee commentarios; qui tres libros, me petente, dictavit, quinque quoque alios in Zachariam", tłum. własne.

${ }^{14}$ Tenże, De viris illustribus 109, PL 23, 705A, PSP 6, 122.

${ }^{15}$ Tenże, Prologus in Zachariam prophetam PL 25, 1418A.

${ }^{16} \mathrm{Na}$ temat odkryć w Tura zob. E. Klostermann, Der Papyrusfund von Tura, ThLZ 73 (1948) $\mathrm{nr}$ 1, 47-50; H.-Ch. Puech, Les nouveaux écrits d'Origène et de Didyme découverts à Toura, RHPR 31 (1951) 293-329; L. Doutreleau, Que savons-nous aujourd'hui des papyrus de Toura, RSR 43 (1955) 161-176; L. Koenen - L. Doutreleau, Nouvel inventaire des papyrus de Toura, RSR 55 (1966) 547-564. 
on powstał. Hieronim posłużył się komentarzem Aleksandryjskiego egzegety i napisał własny 20 lat później ${ }^{17}$. Porównując jeden i drugi komentarz dochodzimy do wniosku, że w wielu miejscach Hieronim jest zależny od Dydyma ${ }^{18}$. Hieronim opracował go bardzo szybko, bo w ciagu 25 dni. Miał do dyspozycji także inne komentarze do tego samego proroka, mianowicie Hipolita i Orygenesa. Wolno zatem stwierdzić, że trzy komentarze posłużyły Hieronimowi jako swoista inspiracja. Czerpał od każdego z autorów pewne myśli, najwięcej jednak wziął od Dydyma. Wybrane przez siebie teksty skracał, streszczał, niekiedy coś do nich dorzucał. Nie można jednak zarzucić Hieronimowi, że niewolniczo kopiował obce teksty, on raczej je przekładał i korzystał z nich jak z przygotowanego materiału do swojego własnego komentarza. Należy również zaznaczyć, że komentarz Dydyma jest dłuższy od Hieronimowego. Komentarz Dydyma składa się z pięciu ksiąg, Hieronima zaś z trzech.

3. Zależność Hieronima od Dydyma. Porównując teksty Dydyma i Hieronima można dopatrzeć się w nich dużych zbieżności związanych najpierw z cytowaniem Pisma Świętego. Hieronim z całą pewnością zapożyczył wiele odniesień biblijnych i używał ich w takim samym porządku jak Dydym. Oto kilka przykładów. Kiedy Dydym powołuje się na jakiś psalm bez podania jego numeru, Hieronim czyni tak samo. Podobnie jest w sytuacji odwrotnej, kiedy Aleksandryjczyk wskazuje na konkretny numer psalmu, Hieronim robi to samo. Z drugiej strony należy dodać, że Hieronim skłaniał się do podawania większej ilości numerów psalmów niż Dydym. Kiedy Dydym mylił się w jakimś cytacie, ten sam błąd można spotkać u Hieronima. Oto kilka przykładów wspomnianych zbieżności związanych z cytowaniem Pisma Świętego:

a) Komentarz do Za 8, 11-12. W tekście proroka czytamy m.in. takie słowa: „Winnica wydawać będzie swój owoc, ziemia będzie obdarzać swymi płodami, a niebo dostarczy wilgoci”. Komentując ostatnie słowa księgi proroka „niebo dostarczy wilgoci”, Dydym stwierdza, że „zrozumiemy, jaka jest ta wilgoć kiedy poznamy, jakie jest niebo, które ją ześle" i dochodzi do wniosku, że niebem tym jest „człowiek, który nosi obraz człowieka niebieskiego” (1Kor 15, 49), i którego „ojczyzna jest w niebie” (Flp 3, 20). Swoją wypowiedź podsumowuje:

„O wszystkich ludziach uznanych za obraz Zbawiciela niebieskiego, powiedziane jest w Psalmie 18, w którym słowo niebo użyte zostało w liczbie mnogiej: «Niebiosa głoszą chwałę Boga, o działaniu rąk jego mówi nieboskłon» (Ps 18, 2)"19.

Św. Hieronim, podobnie jak Dydym, powołuje się na ten sam 18 Psalm i w identyczny sposób komentuje Zachariaszowe słowa: „Lecz i niebiosa

\footnotetext{
${ }^{17}$ Swój komentarz Dydym opracował w 387 r.

${ }^{18}$ Por. L. Doutreleau, Introduction, w: Didym L'Aveugle, Sur Zacharie, SCh 83, Paris 1962, 129.

${ }_{19}$ Didymus Alexandrinus, In Zachariam II 339, ed. L. Doutreleau, SCh 84, Paris 1962, 594, tłum. własne.
} 
dadzą wilgoć swoją, o których w psalmie 18 zostało napisane: Niebiosa głoszą chwałę Boga, a dzieła rąk jego zapowiada nieboskłon"20.

b) Komentarz do Za 9, 13. Prorok mówi w imieniu Boga: „Napiąłem cię bowiem, Judo, jako swój łuk, nasyciłem Efraima i pobudzę twoje, Syjonie, dzieci, przeciw dzieciom Hellenów". Dydym komentuje to zdanie słowami Psalmu 77, 9: „Synowie Efraima napinali swe łuki i miotali strzały, a w dniu bitwy uciekli" 21 .

Z kolei św. Hieronim pisze:

„Następnie, zgodnie z głębszym zrozumieniem (altiorem intelligentiam), Efraim odnosi się do wielkiej ilości herezji (refertur ad haeresum multitudinem), które interpretuje się jako wydawanie plonu (quae interpretatur

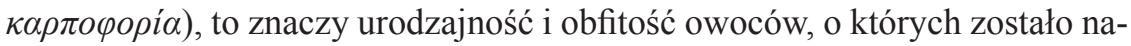
pisane w Psalmie 77: «Synowie Efraima napinając łuki i miotając strzałami, w dniu wojny uciekli»"

c) Komentarz do Za 9, 13. Dydym, ponownie nawiązując do wspomnianych przez proroka Zachariasza strzał, powołuje się na Psalm 44, 6: „Twoje, o najdzielniejszy, strzały ostro zakończone"23. W komentarzu św. Hieronima, przy interpretacji tego samego fragmentu proroka Zachariasza odnajdujemy ten sam psalm 44, 6: „Sagittarius, ut in quadragesimo quarto psalmo: Sagittae tuae acutae potentissimae"24.

d) Komentarz do Za 9, 13. Dydym pisze, że wcześniej już odwołał się do konkretnego cytatu, mianowicie do Psalmu 44, 4-5, który brzmi: „Przypasz, o najdzielniejszy, miecz do swego biodra ku sławie twej kwitnącej urody, ku sławie twej krasy. Weź łuk napięty i ruszaj drogą pomyślności”25.

Hieronim w komentarzu do tego samego wersetu proroka Zachariasza także cytuje Psalm 44: „Przypasz, o najdzielniejszy, miecz do swego biodra. Ze względu na twą urodę i wspaniałość twoją, pomyślnie postępuj naprzód i króluj, pomnażaj prawdę i łaskawość, i sprawiedliwość, i niech cię chwalebnie prowadzi twoja prawica"26.

e) Komentarz do Za 7, 8-9. Bywa też, że Dydym odwołuje się do tekstu proroka Jeremiasza, tymczasem chodziło o Zachariasza ${ }^{27}$, albo też interpretując proroka (Za 12, 9-10a), w jednym miejscu powołuje się dwukrotnie na proroka Izajasza. Tymczasem pierwszy z cytatów nie pochodzi od Izajasza, lecz może stanowić pewien zlepek Iz 42, 1, Ez 36, 27 oraz Łk 1, 35. Brzmi on:

\footnotetext{
${ }^{20}$ Hieronymus, In Zachariam II 8, PL 25, 1471B, thum. własne.

${ }^{21}$ Didymus Alexandrinus, In Zachariam III 187, SCh 84, 708, tłum. własne.

${ }^{22}$ Hieronymus, In Zachariam II 9, PL 25, 1484B, thum. własne.

${ }^{23}$ Didymus Alexandrinus, In Zachariam III 189, SCh 84, 710, thum. własne.

${ }^{24}$ Hieronymus, In Zachariam II 9, PL 25, 1486D.

${ }^{25}$ Didymus Alexandrinus, In Zachariam III 194, SCh 84, 712, thum. własne.

${ }^{26}$ Hieronymus, In Zachariam II 9, PL 25, 1487A, thum. własne.

${ }^{27}$ Por. Didymus Alexandrinus, In Zachariam II 151, SCh 84, 492.
} 
„Dam tobie mojego Ducha”28. W tym samym zdaniu, nieco dalej, cytat jest dosłowny i zgadza się z wcześniejszą zapowiedzią, że chodzi o zdanie z Izajasza 42, 2: „Udzieliłem jemu swego ducha”29.

W komentarzu św. Hieronima odnajdujemy ten sam błąd, co wyraźnie wskazuje na to, że skopiował on ten tekst od Dydyma, zarówno w przypadku powołania się na Jeremiasza, chociaż chodziło o Zachariasza, jak i w drugim, gdy mieliśmy do czynienia z przypisaniem dwóch cytatów prorokowi Izajaszowi ${ }^{30}$.

f) Komentarz do Za 7, 8. Podobne zjawisko kopiowania tekstów biblijnych bez ich sprawdzania odnajdujemy w przypadku powoływania się jednocześnie na kilka fragmentów biblijnych, zwłaszcza wtedy, gdy cytowane są jeden po drugim. Dydym w swoim komentarzu posługuje się składanką złożoną z trzech tekstów: „Jednakowo będziesz sądził małego i wielkiego. Nie będziesz liczył się z niczyją powierzchownością” (Pwt 1, 17) plus „W wydawaniu słusznego wyroku nie bądź pobłażliwy nawet dla ubogiego" (Wj 23, 3) plus „bo to jest w imieniu Boga” (Pwt 1, 17)

Okazuje się, że św. Hieronim stosuje taką samą metodę, łączy mianowicie te same teksty, w taki sam sposób jak Dydym i w odniesieniu do identycznego komentowanego wersetu proroka Zachariasza $(7,8)^{32}$.

g) Komentarz do Za 14, 16. W tym fragmencie komentarza Dydym świadomie parafrazuje tekst biblijny zestawiając ze sobą Pwt 6, 20-25 i Kpł 23, 43: „Kiedy w przyszłości syn twój postawi ci pytanie: Po co te namioty? Odpowiesz jemu: Dawno temu przebywaliśmy w [Egipcie] jako obcy i [Bóg] wyprowadził nas stamtąd na pustynię; dlatego wznosimy święte namioty, byśmy patrząc na nie każdego roku nie zapominali wielkiego dobrodziejstwa"33.

Tymczasem św. Hieronim powtarza tekst Dydyma i uznaje go nawet za dosłowny cytat:

„Et cum te, inquit, interrogaverit filius tuus cras, dicens: Quid sibi volunt haec tabernacula? Respondebis ei: Multo tempore peregrinati sumus in Aegypto, de qua eduxit nos Dominus in solitudinem, et idcirco tabernacula suscitamus, ut beneficiorum Dei omni tempore recordemur, cum coeperimus habitare in urbibus" ${ }^{\prime 3}$.

Przytoczone przykłady pokazały, że Hieronim musiał mieć duże zaufanie do Dydyma w odniesieniu do cytowanych tekstów Pisma Świętego. Dostrzec można $\mathrm{w}$ tym względzie wiele zapożyczeń, wręcz przepisywania od

\footnotetext{
${ }^{28}$ Por. tenże IV 245, SCh 85, Paris 1962, 930, tłum. własne.

${ }^{29}$ Por. tamże, tłum. własne.

${ }^{30}$ Por. Hieronymus, In Zachariam II 7, PL 25, 1462B-C; III 12, PL 25, 1513D.

${ }^{31}$ Por. Didymus Alexandrinus, In Zachariam II 138, SCh 84, 484, thum. własne.

${ }^{32}$ Por. Hieronymus, In Zachariam II 7, PL 25, 1462A.

${ }^{33}$ Didymus Alexandrinus, In Zachariam V 159, SCh 85, 1058, tłum. własne.

${ }^{34}$ Hieronymus, In Zachariam III 14, PL 25, 1536B.
} 
Aleksandryjczyka biblijnych fragmentów. Wskazują na to nie tylko popełniane w tych samych miejscach błędy, ale też używanie jako dowodu przy wyjaśnianiu niektórych fragmentów, tych samych cytatów.

Wspomniane podobieństwo można dostrzec także w bardzo zbieżnym, by nie powiedzieć, takim samym odczytywaniu tekstów biblijnych. Tak samo jak w poprzednim przypadku, pokażemy to na kilku przykładach pochodzących z komentarza Dydyma i Hieronima do tego samego proroka.

Dydym Aleksandryjski i św. Hieronim, podczas komentowania Księgi Zachariasza odwołują się niekiedy do tego, że czytali już te informacje w pewnych bliżej nieokreślonych tekstach. Nie wiadomo jednak, czy tak rzeczywiście było, zwłaszcza że jest to niemożliwe do sprawdzenia. Dydym w jednym miejscu swojego komentarza stwierdza:

„Czytałem wyjaśnienie w jakimś komentarzu, który chce, żeby czterej rzemieślnicy oznaczali czterech Ewangelistów. Pozostawiam to, jeśli tak jest, ocenie tych, którzy przeczytają tego autora" ${ }^{35}$.

Kilka stron dalej w kilku słowach powraca do tej interpretacji, zachęca do tego, by zadowolić się tym, co zostało na ten temat powiedziane i podejmuje wyjaśnienia związane z kolejnymi tekstami biblijnymi ${ }^{36}$. Hieronim posługuje się niemalże identycznymi słowami, jak Dydym i stwierdza, podobnie jak on: „Czytałem w jakichś komentarzach, że czterej rzemieślnicy oznaczają czterech Ewangelistów" ${ }^{\prime 37}$. W dalszej zaś części swojego komentarza, różni się od Aleksandryjczyka. Chociaż w tym samym miejscu co on, powraca do tekstu, podejmuje się jednak podać jeszcze inne wyjaśnienia związane z czterema rzemieślnikami oznaczającymi czterech Ewangelistów ${ }^{38}$.

Kolejne podobieństwo dostrzec można w zdecydowanym i szybkim przechodzeniu od jednego do drugiego tematu. Przykładem jest następująca wypowiedź Dydyma:

„aby nie powtarzać się kilka razy, zadowolimy się tym, co zostało do tej pory

powiedziane i przejdźmy do następnej kwestii" ${ }^{\prime 39}$.

Okazuje się, że Hieronim, tak samo jak Dydym i w komentarzu do tego samego fragmentu (por. Za 14, 11), obawia się powtórzeń i używa podobnego argumentu, co Aleksandryjczyk: ,już wystarczająco długo wyjaśnialiśmy i dlatego teraz zamilczmy"

W innym zaś fragmencie Dydym usprawiedliwia się, że kończy w tym miejscu swoje wyjaśnienie, ponieważ komentarz nie wszystko musi zawierać:

\footnotetext{
${ }^{35}$ Didymus Alexandrinus, In Zachariam I 95, SCh 83, 242, tłum. własne.

${ }^{36}$ Por. tenże I 406, SCh 83, 406-408.

${ }^{37}$ Hieronymus, In Zachariam I 2, PL 25, 1429C, tłum. własne.

${ }^{38}$ Por. tenże II 6, PL 25, 1454B.

${ }^{39}$ Didymus Alexandrinus, In Zachariam V 101, SCh 85, 1026, tłum. własne.

${ }^{40}$ Hieronymus, In Zachariam III 14, PL 25, 1530C, thum. własne.
} 
„,należy zadowolić się tym, co zacytowaliśmy, aby to dzieło, które jest komentarzem, nie osiagnęło nieproporcjonalne rozmiary"41.

Hieronim zaś, niemal identycznie, uzasadnia powód zatrzymania się w komentowaniu fragmentu proroka. Pisze on, że

„,nie tworzymy długich i ukwieconych traktatów, w których toczy się przyjemna rozmowa, lecz piszemy komentarze, których zadaniem jest przejść od tego, co jest oczywiste do rozprawiania nad niejasnymi fragmentami" 42 .

Kolejny przykład tematycznie łączy się z poprzednimi. Dydym pokornie przyznaje, że to, co zostało wyjaśnione, z całą pewnościąjest niewystarczające:

„Po rozważeniu tekstu, zgodnie z naszą możliwością, która jest bardzo słaba, przedstawimy dalszy ciąg proroka" ${ }^{\prime 43}$.

Takie samo przeświadczenie, co Dydym posiada Hieronim na temat tego, co zostało do tej pory wyjaśnione: „Mówiliśmy te rzeczy podobni do tych, którzy wędrują, aby mężowie znieść mogli nasze słabe talenty"44.

O wpływie Dydyma czy też zapożyczaniu z jego komentarza przez Hieronima świadczą nie tylko cytacje biblijne znajdujące się w tym samym miejscu i występujące w takim samym porządku, ale także czynione liczne aluzje do konkretnych osób. Przykładem jest dwukrotne powoływanie się w tym samym miejscu komentarza na historyka Józefa Flawiusza, zarówno przez Dydyma ${ }^{45}$ jak i Hieronima ${ }^{46}$. Podobieństwa widoczne są także w wielu innych miejscach. Kiedy Dydym komentuje Za 14, 9-11, definiuje użyte przez proroka wyrażenie „,brama narożna” i dochodzi do przekonania, iż ,nie jest to nic innego jak przerwanie prostej linii" 47 . Tego samego zdania jest św. Hieronim, który wyjaśnia: ,Omnis angulus rectam lineam frangit”48.

Wymieniany już wielokrotnie wpływ Dydyma na Hieronima widoczny jest także we fragmencie, w którym Aleksandryjczyk wspomina o prześladowaniach Kościoła, prawdopodobnie za czasów cesarza Dioklecjana ${ }^{49}$. Także Hieronim zatrzymuje swoją uwagę na prześladowaniach w tym samym

${ }^{41}$ Didymus Alexandrinus, In Zachariam II 185, SCh 84, 510, tłum. własne.

${ }^{42}$ Hieronymus, In Zachariam II 7, PL 25, 1463C, tłum. własne.

${ }^{43}$ Didymus Alexandrinus, In Zachariam I 343, SCh 83, 376, tłum. własne.

${ }^{44}$ Hieronymus, In Zachariam I 6, PL 25, 1446D - 1447A, thum. własne.

${ }^{45}$ Por. Didymus Alexandrinus, In Zachariam IV 193, SCh 85, 900; V 29, SCh 85, 982.

${ }^{46}$ Por. Hieronymus, In Zachariam III 12, PL 25, 1509A; III 14, 1522D.

${ }^{47}$ Didymus Alexandrinus, In Zachariam V 107, SCh 85, 1030, thum. własne.

${ }^{48}$ Hieronymus, In Zachariam III 14, PL 25, 1531A.

${ }^{49}$ Por. Didymus Alexandrinus, In Zachariam II 281-286, SCh 84, 560-564. Do tematu prześladowań Dydym powraca także tamże V 123, SCh 85, 1038-1040. Ani w pierwszym, ani w drugim przypadku nie precyzuje, o jakie prześladowania chodzi. Wydaje się, że Dydym miał na myśli długo trwające prześladowania, jakie dotknęły Egipt (303-311). Rozpoczęły się one jeszcze w czasach cesarza Dioklecjana (303), a po jego abdykacji (305) były kontynuowane przez kolejnych władców Wschodu, aż do roku 311. 
miejscu komentarza (por. Za 8, 6 i 14, 12) ${ }^{50}$. Dostarcza jednak więcej informacji, wymienia bowiem precyzyjnie cesarzy, za czasów których prześladowani byli chrześcijanie ${ }^{51}$. Chodzi tutaj o Decjusza (249/250), Waleriana (257/258) i Dioklecjana (303-305) $)^{52}$.

\section{Metody interpretacji proroka Zachariasza u Dydyma i Hieronima.} Lektura komentarza Dydyma do Księgi proroka Zachariasza prowadzi do wniosku, że stosowana przez niego metoda egzegetyczna nie jest wszędzie jednakowa. Nie oznacza to zaniechania przez niego alegorii na rzecz typologii, ponieważ na każdym niemalże kroku spotykamy głębszą interpretację tekstu wspomnianego proroka. Nie porzuca też Dydym linii aleksandryjskiej, zwłaszcza zaś orygenesowskiej, w której był wychowany i dobrze z nią obeznany. Odnosi się to raczej do dwóch schematów, które stosuje w swojej metodzie egzegetycznej. W przypadku jednego jak i drugiego schematu możemy wyróżnić cztery etapy, w których używa technicznych terminów służących do interpretacji słów proroka Zachariasza.

Pierwszy schemat rozpoczyna się od krótkiego wyjaśnienia tekstu biblijnego. Dydym czyni to dosyć zwięźle, zazwyczaj parafrazuje interpretowany fragment ${ }^{53}$. Technicznym terminem, jakiego używa Aleksandryjczyk na tym

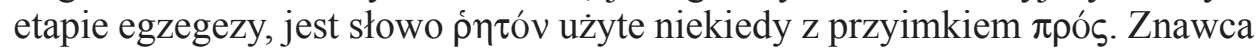
metody interpretacji tekstu Zachariasza dokonanej przez Dydyma, Jo Tigche-

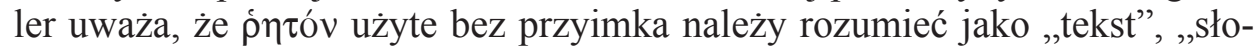
wo”, „coś, co zostało powiedziane”, z przyimkiem natomiast oznacza „w jako takim tekście”, ,tekst jako taki”, ,według tekstu” 54 .

W kolejnym etapie pierwszego schematu swojej egzegezy Dydym wybiera słowa $\mathrm{z}$ tekstu proroka i wskazuje na ich głębsze znaczenie ${ }^{55}$. Podobnie jak poprzednio, tak i tutaj posługuje się technicznym terminem, tym razem $\kappa \alpha \tau^{\prime} \alpha^{\prime} \lambda \lambda \eta \gamma o i^{\prime} \alpha \nu$, który występuje w różnych formach i konstrukcjach

${ }^{50}$ Por. Hieronymus, In Zachariam II 8, PL 25, 1467B.

${ }^{51}$ Por. tamże III 14, PL 25, 1532 C.

${ }^{52}$ Por. E. Wipszycka, Kościót w świecie późnego antyku, Warszawa 2006, 99-100.

${ }^{53}$ Przykładem tego etapu jest komentarz do Za 1, 8: „Miałem widzenie podczas nocy, a oto mąż dosiadający ognistego konia znajdował się między dwiema ocienionymi górami, a za nim były konie ogniste, szare, cętkowane i białe”. Dydym wyjaśnia dosłownie ten tekst biblijny w następujący sposób: „Słowo Pana przyszło do Zachariasza podczas nocy i ukazał się jemu mąż dosiadający ognistego konia i znajdujący się pośrodku dwóch ocienionych gór” (I 21, SCh 83, 200, tłum. własne); „Po ognistych koniach, które są za Tym, który jest sławny, wizja pokazuje konie centkowane, szare i białe" (I 25, SCh 83, 204, thum. własne).

${ }^{54}$ Por. J. Tigcheler, Didyme l'Aveugle et l'exégèse allégorique. Étude sémantique de quelques termes exégétiques importants de son commentaire sur Zacharie, trad. de D.F.L. Van WeelderenBakelants, Nijmegen 1997, 65.

${ }^{55}$ Wspomniany już wcześniej tekst Za 1, 8 Dydym komentuje, zgodnie z alegorią, w następujący sposób: „Mąż dosiadający ognistego konia to wcielony Zbawiciel. Ognisty koń to ciało, którym jest odziany” (I 21, SCh 83, 200, thum. własne); „Te góry to są dwa Testamenty” (I 22, SCh 83, 202, tłum. własne). 
gramatycznych (np. imiesłów czasownika $\alpha \lambda \lambda \eta \gamma o \rho \varepsilon \hat{\imath} \sigma \theta \alpha$; rzeczownik

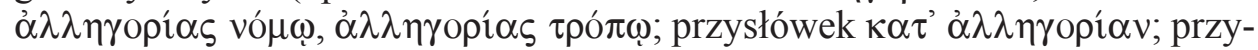

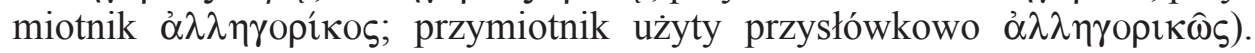
Niezależnie od występującej formy gramatycznej, $\dot{\alpha} \lambda \lambda \eta \gamma$ opí $\alpha$ oznacza, że coś lub ktoś został przedstawiony w jakiejś figurze bądź też w obrazie. Należy jednak zaznaczyć, że na tym etapie egzegezy nie mamy jeszcze do czynienia z pełnym duchowym odczytaniem tekstu biblijnego ${ }^{56}$.

Dopiero następny, trzeci etap pozwala dostrzec właściwy, tzn. duchowy sens tekstu biblijnego ${ }^{57}$. Dydym także używa technicznego terminu na określenie swojej metody egzegetycznej, mianowicie $\kappa \alpha \tau^{\prime} \alpha \dot{\alpha} \alpha \gamma \omega \gamma \eta \dot{v}$. Podobnie jak przy alegorii, tak i tutaj pojawiają się różne formy gramatyczne tego wy-

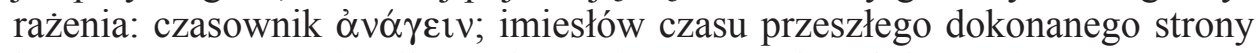

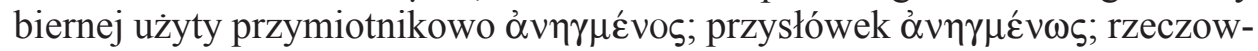
nik $\dot{\eta} \alpha \grave{\alpha} \nu \alpha \omega \gamma \eta \dot{\eta}$ użyty z rodzajnikiem, bez niego i z zaimkami. Ten duchowy sens Dydym uznaje za najważniejszy ${ }^{58}$.

Ostatni etap w tym pierwszym schemacie egzegetycznym Aleksandryjczyka to wyjaśnienie dosłowne opisanych zdarzeń, osób czy też sytuacji. Dlate-

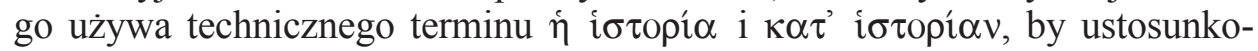
wać się do opisanych przez proroka zdarzen ${ }^{59}$. Autor komentarza odnosi się do biblijnych opisów, które dotyczą Chrystusa, a tym samym uznaje je za fakty

${ }^{56}$ Por. Czyżewski, Chrystologia w Komentarzu do Zachariasza, s. 48-51.

${ }^{57}$ Tekst Za 1, 8 Dydym komentuje zgodnie z sensem anagogicznym w następujący sposób: „Ognisty koń to ciało, którym jest odziany, ponieważ zgodnie z naturą ciało ludzkie jest czerwone przez krew, która w nim krąży” (I 21, SCh 83, 200, thum. własne); „Te góry to są dwa Testamenty, a jeśli są one urodzajne i zacienione to z powodu bogactwa myśli i obfitości wyrażeń dotyczących nauki o Bogu i o wcieleniu. A ponieważ dużo jest niejasności w każdej przepowiedni, która wyrażona jest tajemniczo i dogłębnie w dwóch Testamentach, to dlatego podczas nocy prorok zobaczył, że ten mąż wsiada na konia zgodnie z tym, co o nim napisano: «okrył się ciemnościami, aby się schować» (Ps $17,12)$, gdyż ten tekst słusznie wskazuje, że to, co jest trudne do zrozumienia, zakryte jest przed spojrzeniami, podobnie jak w innym: «Przepaść jak szata otaczająca go» (Ps 17, 12)” (I 22, SCh 83, 202, thum. własne).

${ }^{58}$ Szerzej na ten temat por. Czyżewski, Chrystologia w Komentarzu do Zachariasza Dydyma, s. $43-48$.

${ }^{59}$ Oto przykład wyjaśnienia w sensie historycznym Za 1, 8: „Lecz osoby przybyłe po wcieleniu nie są jedyne, które mają ten centkowany kolor; ci, którzy przybyli przed, mają go również, ponieważ uczestniczą w «nieskończenie wielorakiej mądrości Boga» (Ef 3,10). Wystarczy wspomnieć o dwóch spośród nich” (I 27 I 22, SCh 83, 206, tłum. własne); „Izajasz, otrzymawszy od Boga boskie wizje, posiadał wszystkie równocześnie rodzaje wspomagających słów. Prorok widząc rzeczy przyszłe okiem proroczym powiedział: «Oto Dziewica pocznie w swoim łonie i porodzi syna» (Iz 7, 14)” (I 28 I 22, SCh 83, 206, thum. własne); „Podobnie Dawid jako liryk powiedział: «Boże, będziemy Tobie śpiewać pieśń nową» (Ps 143, 9), jako prawodawca: «Odwróć się od zła i czyń dobro» (Ps 33, 15), jako widzący przyszłość powiedział: «Bóg bogów ukaże się na Syjonie» (Ps 83, 8). Nie pominął także historycznego opowiadania, ponieważ przypomniał szczegółowo w większości psalmów liczbę historycznych wydarzeń, które stały się z korzyścią dla Izraelitów a ze szkodą dla Egipcjan i Faraona" (I 29 I 22, SCh 83, 206, tłum. własne). 
historyczne, ponieważ przepowiadały je osoby żyjące w czasach Starego Testamentu $^{60}$. Należy też dodać, że pierwszy etap i ostatni, chociaż wyglądają na bardzo do siebie podobne, ponieważ odnoszą się do interpretacji dosłownej tekstu biblijnego, nie można traktować jako synonimy. To bowiem, co określa u Dy-

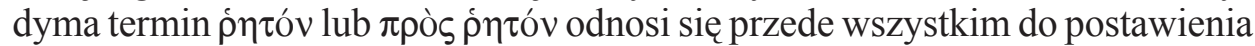
pytania, co mówi tekst biblijny jako taki i stanowi jego parafrazę. Gdy chodzi

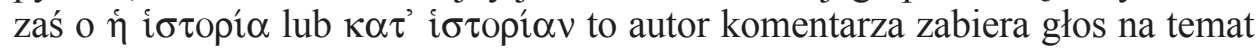
opisanych w biblijnym fragmencie zdarzeń i próbuje odpowiedzieć na pytanie, czy przedstawione w nim fakty zaistniały albo czy mogły się wydarzyć.

Drugi schemat, jakim posługuje się Dydym zawiera także cztery elementy i wydaje się, że jest bardziej logiczny i przejrzysty od pierwszego do tej pory omówionego. Najpierw komentator wyjaśnia, co mówi tekst proroka Zacha-

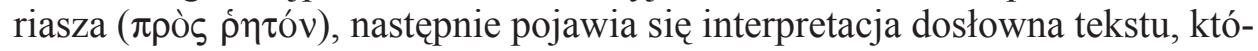
ra przede wszystkim bierze pod uwagę opisane wydarzenia ( $\kappa \alpha \tau^{\prime} i \sigma \tau o \rho^{\prime} \alpha \nu$ ), w dalszej kolejności Dydym odkrywa głębsze znaczenie poszczególnych słów i opisanych zdarzeń ( $\kappa \alpha \tau^{\prime} \alpha ̉ \lambda \lambda \eta \gamma o p^{\prime} \alpha \nu$ ), na końcu zaś interpretuje alegorycz-

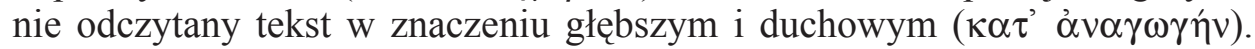
W ostatnim etapie bardzo często nie ogranicza się do wskazania na jedno tylko duchowe i głębsze znaczenie, ale co rusz Aleksandryjczyk zwracając się do czytelników mówi: „,według innej interpretacji”.

O Hieronimie można powiedzieć, że przejął od Dydyma alegorię. Znał hebrajski, co z pewnością dodaje jego komentarzowi bardziej naukowego charakteru $^{61}$. Spotykamy u niego liczne analizy filologiczne, czego nie można powiedzieć o komentarzu Dydyma. One też często poprzedzają wyjaśnienia dosłowne lub historyczne, po których następuje wyjaśnienie alegoryczne i moralne.

Hieronim we wstępie do swojego komentarza do proroka Zachariasza powołuje się na Orygenesa, który napisał dwie księgi na temat tego proroka ${ }^{62}$, wspomina także o Hipolicie ${ }^{63}$ i na koniec o Dydymie. Zarzuca im jednak, że

„cała ich egzegeza była alegoryczna a historię zaledwie dotknęli. Dlatego pragnąc naśladować owego ojca rodziny, który «ze swego skarbca wyciaga rzeczy nowe i stare» (Mt 3, 52) i oblubienicę z Pieśni nad pieśniami, która mówi: «Świeże ze starymi strzegłam, dla ciebie, mój umiłowany» (Pnp 7, 14): domieszałem tropologię (tropologiam miscui) do historii naszych Hebrajczyków, aby budować na skale a nie na piasku (por. Mt 7, 26) i posta-

\footnotetext{
${ }^{60}$ Por. Czyżewski, Chrystologia w Komentarzu do Zachariasza, s. 29.

${ }^{61}$ Por. M. Jóźwiak, Princeps exegetarum a język hebrajski na podstawie Quaestiones hebraicae in Genesim, VoxP 36 (2016) t. 65, 186.

${ }^{62}$ Orygenes zinterpretował tylko część proroctwa Zachariasza, mianowicie rozdziały $1-6,8$.

${ }^{63}$ Św. Hieronim nie tylko w Prologus In Zachariam prophetam wspomina Komentarz do Zachariasza Hipolita. Także mówi o nim w De viris illustribus (61). Nic jednak o tym komentarzu nie wiadomo i prawdopodobnie Hieronim w ogóle się nim nie posługiwał. Por. M. Simonetti, Między dostownościq a alegoriq, Myśl Teologiczna, tłum. T. Skibiński, Kraków 2000, 339.
} 
wiłem mocny fundament, który, jak napisał Paweł architekt, że on położył (por. 1Kor 3, 10)"'64.

Chcąc określić metodę egzegetyczną używaną przez św. Hieronima należy powiedzieć, że stosuje on podwójny schemat. Najpierw mamy do czynienia z egzegezą dosłowną, następnie zaś duchową. Sam o tym zaświadcza, kiedy mówi:

„Te rzeczy, jak zwykle, najpierw zapowiedzieliśmy zgodnie z sensem do-

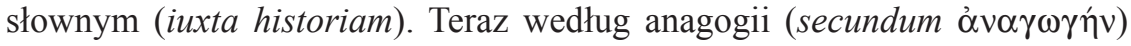
krótko należy wyjaśnić" ${ }^{5}$.

Rozpoczynając komentowanie znanego nam już od Dydyma fragmentu Za 1, 8, Hieronim pisze: „Najpierw wyłożymy historię (primum disseramus historiam)"66. W dłuższym wywodzie wyjaśnia, kim w dosłownym znaczeniu jest jeździec i różnokolorowe konie. Hieronim uważa, że jeździec z wizji Zachariasza to, według Hebrajczyków, Michał anioł, białe konie

„oznaczają Medów i Persów, ponieważ za ich czasów skończyła się niewola i rozpoczęła odnowa świątyni, inni to Macedonianie, spośród których niektórzy byli przyjaciółmi, inni prześladowcami" ${ }^{67}$.

Drugi etap egzegezy Hieronima to interpretacja alegoryczna o temacie chrystologicznym. W interesującym nas tekście jest ona identyczna z tą, którą spotkaliśmy u Dydyma. Hieronim nawiązując do jeźdźca i koni z wizji Zachariasza wyjaśnia:

„Mężem zaś, który wspiął się na ognistego konia jest Pan Zbawiciel, który przyjmując nasze ciało, słyszy u Izajasza: «Dlaczego twoje szaty są szkarłatne?» $(\mathrm{Iz} 63,2)$. [...] dwie ocienione góry oznaczają nowe i stare Pisma, o których mówi się, że są najbardziej zapisanymi kartkami, są gajem i ocienionymi lasami, ponieważ zawierają wiele niejasności"68.

Hieronim często też posługuje się wiedzą przejętą od Hebrajczyków, o czym nie omieszkał wspomnieć w Komentarzu do Zachariasza:

„Te słowa znajdujemy u Hebrajczyków. Teraz wykładamy to, co w komentarzach zostało napisane przez kościelnych mężów"

Z tego, co zostało powiedziane, wynika, że św. Hieronim ogranicza się raczej do dwóch sensów egzegezy biblijnej: dosłownego i duchowego. Pierwszy określa terminem historia, drugi zaś nazywa niekiedy łacińskim słowem

\footnotetext{
${ }^{64}$ Hieronymus, Prologus in Zachariam prophetam, PL 25, 1418, tłum. własne.

${ }^{65}$ Tenże, In Zachariam I 1, PL 25, 1419B, tłum. własne.

${ }^{66}$ Tamże, PL 25, 1423A, tłum. własne.

${ }^{67}$ Tamże, tłum. własne.

${ }^{68}$ Tamże, PL 25, 1424C, tłum. własne.

${ }^{69}$ Tamże, tłum. własne.
} 


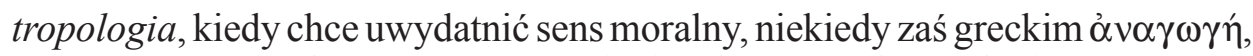
przez co rozumie alegoryczne wyjaśnienie tekstu proroka Zachariasza w sensie duchowym. Sens dosłowny odgrywa w jego egzegezie znacząca rolę, do czego przyznał się, twierdząc, że tego mu właśnie brakuje w komentarzu Orygenesa i Dydyma. Każdy właściwie fragment jego komentarza rozpoczyna się od dokładnej interpretacji wybranego fragmentu proroka w sensie dosłownym. Dopiero po nim następuje wyjaśnienie duchowe i moralne tekstu biblijnego.

\section{$* * *$}

Podsumowując, można powiedzieć, że Hieronim w swojej metodzie egzegetycznej, przynajmniej gdy chodzi o komentarz do proroka Zachariasza, jest bardzo podobny do komentarza Dydyma. Często w taki sam sposób interpretuje wiele tekstów biblijnych, niekiedy mu zaprzecza lub go uzupełnia, lecz zręczność do wykrywania symboli jest u nich taka sama. Można odnieść wrażenie, że Dydym wyznacza drogę, Hieronim zaś po niej kroczy. Louis Doutreleau, który wiele lat zajmował się Dydymem i przełożył m.in. jego Komentarz do Zachariasza, we wstępie do niego napisał, że „studiować alegorię jednego, to studiować ją u drugiego. Różnice dotyczą jedynie detali i nie zmieniają istoty rzeczy" ${ }^{\prime 70}$.

Z drugiej strony należy uczciwie powiedzieć i podkreślić, że mimo wielu zapożyczeń od Dydyma, o czym mogliśmy się przekonać na podstawie analizowanych tutaj przykładów, Hieronim zachowuje swoją niezależność. Jego komentarz jest $\mathrm{z}$ pewnością oryginalny i wnosi wiele ciekawych wątków, chociażby w postaci wyjaśnień odnoszących się do sensu dosłownego, czy też rozważań filologicznych. $Z$ całą pewnością nie można zarzucić mu plagiatu, co w czasach Ojców Kościoła było pojęciem obcym, korzystanie zaś z obcych dzieł rozumiano całkowicie inaczej niż dzisiaj.

\section{THE BOOK OF PROPHET ZECHARIAH IN THE EXEGESIS OF SAINT JEROME AND DIDYMUS OF ALEXANDRIA}

\section{(Summary)}

The subject of analysis are two biblical commentaries to the Book of the prophet Zechariah. First commentary is written by Didymus of Alexandria. The second is the fruit of saint Jerome's thought, prince of exegetes. Analysis of these two comments leads us to the conclusion of a very high resemblance of these works. Numerous fragments of a saint Jerome's comment are convergent with those written by Didymus or are complementary to his interpretation. We get the impression, that Didymus determines the way, after which Jerome goes. Honestly speaking,

\footnotetext{
${ }^{70}$ Doutreleau, Introduction, s. 135, tłum. własne.
} 
despite some borrowings from Didymus, Jerome maintains a certain independence even in appreciation of literal interpretation of Scripture. Moreover, in many places he uses philological explanations or just supplements Didymus. We cannot forget, that Jerome asked Dydimus to write this commentary to the Zechariah prophet, and probably that's why he allowed himself to use it, as he wished to.

Key words: Didymus the Blind, saint Jerome, exegesis, the prophet Zechariah, allegory, Bible commentary.

Słowa kluczowe: Dydym Aleksandryjski, Hieronim, egzegeza, prorok Zachariasz, alegoria, komentarz biblijny.

\section{BIBLIOGRAFIA}

\section{Źródła}

Didymus AleXandrinus, In Zachariam, ed. L. Doutreleau, SCh 83-85, Paris 1962.

Hieronymus, De viris illustribus, PL 23, 601-720, tłum. W. Szołdrski: Św. Hieronim, O znakomitych mężach, PSP 6, Warszawa 1970, 23-149.

Hieronymus, Epistulae, ŹMT 54, 55, 61, 63 i 68 [wyd. łacińsko-polskie, tekst łac. i oprac.

H. Pietras, tłum. J. Czuj, oprac. M. Ożóg, t. 1-5], Kraków 2010-2013.

Hieronymus, In Zachariam, PL 25, 1416-1542.

Hieronymus, Prologus in Osee prophetam, PL 25, 815-820.

Hieronymus, Prologus in Zachariam prophetam, PL 25, 1416-1418.

Rufinus, Apologia contra Hieronymum, ed. M. Simonetti, CCL 20, Turnholti 1961, 29123, tłum. A. Smaroń: Św. Rufin z Akwilei, Apologia przeciw Hieronimowi, w: Św. Rufin z Akwilei, Obrona przed zarzutami Hieronima, ŹMT 29, Kraków 2003, 43-150.

\section{Opracowania}

Bardy G., Didyme l'Aveugle. Essai de théologie historique, Paris 1910.

Czyżewski B., Chrystologia w Komentarzu do Zachariasza Dydyma Aleksandryjskiego, Gniezno 1996.

CzyżEwski B., Dydym Aleksandryjski - Ojciec zapomniany, SG 11 (1997) 305-312.

CzyżEwski B., Obraz Kościoła w Komentarzu do Zachariasza Dydyma Aleksandryjskiego, VoxP 28 (2008) t. 52/1, 109-122.

Doutreleau L., Introduction, w: Didym l'Aveugle, Sur Zacharie, SCh 83, Paris 1962 , 13-188.

Doutreleau L., Que savons-nous aujourd'hui des papyrus de Toura, RSR 43 (1955) 161-176.

Doutreleau L., Vie et survie de Didyme l'Aveugle du IV siècle à nos jours, „Les Mardis de Dar El-Salam" (1956-57), Paris - Le Caire 1959, 33-92.

Jóźwiak M., Princeps exegetarum a język hebrajski na podstawie Quaestiones hebraicae in Genesim, VoxP 36 (2016) t. 65, 185-199.

KaоKA K., Aretologia Dydyma Aleksandryjskiego, Lublin 2014 (mps AKUL).

Klostermann E., Der Papyrusfund von Tura, ThLZ 73 (1948) nr 1, 47-50.

Koenen L. - Doutreleau L., Nouvel inventaire des papyrus de Toura, RSR 55 (1966) 547-564.

Nakonieczny R., Nauka o duszy w antropologii Dydyma Aleksandryjskiego, „Symbolae Philologorum Posnaniensium Graecae et Latinae” 21 (2011) fasc. 2, 157-180. 
Nakonieczny R., O antropologii Dydyma Aleksandryjskiego (In Genesim), Katowice 2005.

NakonieCZny R., Teologia kreacji - między obrazem a podobieństwem (na podstawie In Genesim Dydyma Aleksandryjskiego), VoxP 25 (2005) t. 48, 105-123.

Nakonieczny R., Terminologia antropologiczna w Komentarzu do Księi Rodzaju Dydyma Aleksandryjskiego, Katowice 2004 (mps AUŚ).

Pancerz R.M., Hermeneutyka antropomorfizmów biblijnych u Dydyma Ślepego, VoxP 30 (2010) t. 55, 521-534.

Puech H.-Ch., Les nouveaux écrits d'Origène et de Didyme découverts à Toura, RHPR 31 (1951) 293-329.

Simonetti M., Między dostownościq a alegoriq. Przyczynek do historii egzegezy patrystycznej, Myśl Teologiczna, tłum. T. Skibiński, Kraków 2000.

Szram M., Elementy pitagorejskiej symboliki liczb w dziełach Dydyma Ślepego, „Studia Graeco-Latina" 4 (2002) 165-179.

Szymańska-Kuta D., Dydym Ślepy. Materiaty bibliograficzne, VoxP 35 (2015) t. 63, 567-581.

Tigcheler J., Didyme l'Aveugle et l'exégèse allégorique. Étude sémantique de quelques termes exégétiques importants de son commentaire sur Zacharie, trad. de D.F.L. Van Weelderen-Bakelants, Nijmegen 1997.

Wielgus S., Badania nad Bibliq w starożytności i w średniowieczu, Lublin 1990.

WiPsZYCKa E., Kościół w świecie późnego antyku, Warszawa 2006.

ŻElazny J., Wstęp, w: Św. Rufin z Akwilei, Obrona przed zarzutami Hieronima, ŹMT 29, Kraków 2003, 5-22. 